\title{
Taxonomic Relationships among Clostridium novyi Types A and B, Clostridium haemolyticum and Clostridium botulinum Type C
}

\author{
By SHINICHI NAKAMURA, * IMIKO KIMURA, \\ KIYOTAKA YAMAKAWA AND SHOKI NISHIDA \\ Department of Bacteriology, School of Medicine, Kanazawa University, Kanazawa 920, Japan
}

(Received 6 October 1982)

\begin{abstract}
The present study was undertaken to examine the genetic relationships among the closely related species, Clostridium novyi types $\mathrm{A}$ and $\mathrm{B}, C$. haemolyticum and $C$. botulinum type $\mathrm{C}$. These species were tested for DNA-DNA homology and thermostability of DNA duplexes and sorted into three genetically related groups: I, $C$. novyi type A; II, $C$. novyi type $\mathrm{B}, C$. haemolyticum and one C. botulinum type C strain (Stockholm); III, the remaining C. botulinum type $\mathrm{C}$ strains. A few biochemical criteria corresponding to the genetic differences were recommended to differentiate each group. These studies imply that $C$. haemolyticum might be considered as $C$. novyi type $\mathrm{D}$ and that there are two genetically different groups in $C$. botulinum type C.
\end{abstract}

\section{INTRODUCTION}

Clostridium novyi was divided into four types A, B, C and D on the basis of the production of eight different soluble antigens and to some extent on the disease that they produce in man and animals (Oakley \& Warrack, 1959; Oakley et al., 1947; Willis, 1964). Types A, B and D are pathogenic, and type $C$ is generally recognized as non-pathogenic to laboratory animals. Although $C$. novyi type $\mathrm{D}$ is similar in cultural characteristics and the beta, eta and theta toxins are shared with $C$. novyi type $\mathrm{B}$, it is also considered by some as a separate species, $C$. haemolyticum (Smith, 1975; Smith \& Hobbs, 1974), because the pathogenesis is not related to the production of alpha toxin, which is the lethal toxin of virulent strains of $C$. novyi types A and B, and the disease produced by $C$. novyi type $\mathrm{D}$ is quite unlike that produced by $C$. novyi types $\mathrm{A}$ and B. Clostridium novyi type A is frequently involved in gas gangrene in man and animals, type B causes infectious necrotic hepatitis, a disease found frequently in sheep, and type $\mathrm{D}(C$. haemolyticum) is the causal organism of bacillary haemoglobinuria in cattle (Smith, 1975).

Some strains of $C$. botulinum type $\mathrm{C}$ are culturally indistinguishable from strains of $C$. novyi type A (Holdeman \& Brooks, 1970), except for toxin production. This close relationship is strengthened further by the fact that a non-toxigenic, cured culture of $C$. botulinum type $C$ can be infected with specific phage and induced to produce alpha toxin of C. novyi type A (Eklund et al., 1974), thus becoming totally indistinguishable from $C$. novyi type A.

The purpose of this study was to examine the genetic relationship among the closely related species, $C$. botulinum type $\mathrm{C}, C$. novyi types $\mathrm{A}$ and $\mathrm{B}$, and $C$. haemolyticum by DNA-DNA in vitro molecular hybridization.

\section{METHODS}

Bacterial strains. Bacterial strains used in this study were as follows: toxigenic Clostridium novyi type A strains 140 and 77101 (Nishida \& Nakagawara, 1965; Taguchi \& Ikezawa, 1975); non-toxigenic C. novyi type A strains 3-1116 and 4-1102 (Nishida \& Nakagawara, 1964); C. novyi type B strains 990, GR 2B, GR 8B and GR 11B (Nakamura et al., 1975b; Rutter \& Collee, 1969); C. haemolyticum strains 4507, 6700, 6705 and Shinketsu (Nakamura et al., 1975b); C. botulinum type C strains Stockholm (Eklund \& Poysky, 1972; Inoue \& Iida, 1970), 
85-8 and 95-2 (Serikawa et al., 1977), all of which produce both $C_{1}$ and $C_{2}$ toxins; and C. botulinum type $C$ strains 85-14 and 98-1 (Nakamura et al., 1978) that produce $C_{2}$ but not $C_{1}$ toxin.

Preparation of DNA. Clostridium novyi type A strains were grown at $37^{\circ} \mathrm{C}$ in a medium containing $(\%, w / v)$ : proteose peptone no. 2 (Difco), $2 \cdot 0$; yeast extract (Difco), $0 \cdot 5 ;$ glucose, $1 \cdot 0 ; \mathrm{NaCl}, 0 \cdot 5 ; \mathrm{L}$-cysteine. $\mathrm{HCl}, 0 \cdot 05$ (PYG medium, pH 7.2). Clostridium novyi type B 990, GR 8 B and GR $11 \mathrm{~B}$ were grown in a medium containing $(\%$, w/v): trypticase (BBL), 3.0; yeast extract (Difco), $2 \cdot 0 ;$ glucose, $0 \cdot 5 ; \mathrm{Na}_{2} \mathrm{HPO}_{4} \cdot 12 \mathrm{H}_{2} \mathrm{O}, 0 \cdot 2 ;$ L-cysteine. $\mathrm{HCl}, 0 \cdot 05$ (TYG medium, pH 7-2). Clostridium haemolyticum 4507,6700 and 6705, and C. botulinum type C 85-14 were grown in TYG medium with a concentration of $1.0 \%(\mathrm{w} / \mathrm{v})$ yeast extract (Difco). Clostridium botulinum type C Stockholm, 85-8, 95-2 and 98-1 were grown in a medium containing proteose peptone no. $2($ Difco) $1 \cdot 0 \%(\mathrm{w} / \mathrm{v})$, yeast extract (Difco) $1.0 \%(\mathrm{w} / \mathrm{v})$, glucose $0.5 \%(\mathrm{w} / \mathrm{v}), \mathrm{NaCl} 0.5 \%(\mathrm{w} / \mathrm{v}), \mathrm{L}$-cysteine. $\mathrm{HCl} 0.05 \%(\mathrm{w} / \mathrm{v})$ and liver infusion $15 \%(\mathrm{v} / \mathrm{v})(\mathrm{PYGL}$ medium, $\mathrm{pH} 7 \cdot 2)$. Liver infusion was prepared as follows: $10 \mathrm{~g}$ liver extract (Kyokuto, Tokyo, Japan) was dissolved in $170 \mathrm{ml}$ distilled water, kept at $50{ }^{\circ} \mathrm{C}$ for $60 \mathrm{~min}$, and then boiled for $5 \mathrm{~min}$. The solution was adjusted to $\mathrm{pH} 7.2$ with $\mathrm{NaOH}$ and filtered through Toyo filter paper no. 2 (Toyo, Tokyo, Japan). The filtrate was used as liver infusion. Penicillin $\mathrm{G}\left(50 \mu \mathrm{g} \mathrm{ml}^{-1}\right)$ was added in the late-exponential phase of growth and cultures were incubated for a further $30 \mathrm{~min}$ at $37^{\circ} \mathrm{C}$. The organisms were then harvested by centrifugation, resuspended in $0 \cdot 15 \mathrm{M}-\mathrm{NaCl} / 0 \cdot 01 \mathrm{M}$-EDTA solution at $\mathrm{pH} 8.0$ and lysed with 3 to $5 \%(\mathrm{w} / \mathrm{v}) \mathrm{SDS}$. Clostridium novyi type B GR 2B and C. haemolyticum Shinketsu were grown at $37^{\circ} \mathrm{C}$ for $24 \mathrm{~h}$ in TYG medium. The organisms were then harvested by centrifugation, suspended in $\mathrm{NaCl} / \mathrm{EDTA}$ solution and lysed with $3 \%$ (w/v) SDS.

For the preparation of labelled DNA from $C$. novyi type A 140 and type B 990, C. haemolyticum 6700, and $C$. botulinum type $\mathrm{C}$ Stockholm and $85-8,\left[{ }^{3} \mathrm{H}\right]$ thymidine $[10 \mu \mathrm{Ci}(370 \mathrm{kBq})$; Japan Isotope Association, Tokyo, Japan] was added to $100 \mathrm{ml}$ of the medium used for the isolation of unlabelled DNA of each strain. The organisms were incubated, treated and lysed by the procedure used for the preparation of unlabelled DNA.

In all cases DNA was extracted from the lysate by the method of Marmur (1961).

Test for DNA-DNA homology and the thermostability of DNA duplexes. The percentage DNA-DNA homology and the $T_{m(e)}$ value (the temperature at which $50 \%$ of homologous or heterologous DNA duplexes were dissociated) was estimated as described previously (Nakamura et al., 1975a).

Sugar fermentation tests. These were performed in pre-reduced anaerobically sterilized (PRAS) medium according to the method described by Holdeman \& Moore (1975). Sugars tested were adonitol, arabinose, cellobiose, fructose, galactose, glucose, inositol, inulin, maltose, mannose, melezitose, melibiose, raffinose, ribose, salicin, sorbose, sucrose, trehalose and xylose. The final sugar concentration employed was $1 \%(w / v)$ except for inulin and salicin which were used at the final concentration of $0.5 \%$. The medium $(5 \mathrm{ml})$ was inoculated with $0.1 \mathrm{ml}$ of an overnight culture in liver broth and incubated under oxygen-free $\mathrm{CO}_{2}$ for $3 \mathrm{~d}$ at $37^{\circ} \mathrm{C}$. The pH values of cultures were measured with a Beckman Zeromatic SS-3 pH meter (Beckman-Toshiba, Tokyo, Japan). Further details of evaluation for fermentation are described in the Results.

Other biochemical tests. Tests for reduction of nitrate, production of indole, digestion of milk and casein were performed by the methods of Holdeman \& Moore (1975). Liquefaction of gelatin was examined by the methods of Nakamura et al. (1973) and Holdeman \& Moore (1975). Production of lecithinase and lipase was examined by using Nagler's modified VF blood agar (Nagler's m-VFBA) (Nagler, 1944).

Lecithinase neutralization test. This test was performed on half-antitoxin Nagler's m-VFBA according to the method of Oakley et al. (1947). The antitoxin sera of C. novyi types A and B were purchased from Wellcome.

\section{RESULTS}

\section{DNA-DNA homology}

A total of 17 strains of $C$. novyi types A and B, C. haemolyticum, and C. botulinum type C were examined for DNA-DNA homology with reference DNA from C. novyi type A 140, C. novyi type B 990 or C. botulinum type C 85-8. All of strains tested showed more than $80 \%$ homology with one of the above-mentioned three reference DNAs and separated into three genetically related groups: strains of 80 to $100 \%$ homology with reference DNA from $C$. novyi type A 140 (group I), strains of 84 to $100 \%$ homology with reference DNA from C. novyi type B 990 (group II) and strains of 91 to $100 \%$ homology with DNA from C. botulinum type C 85-8 (group III) (Table 1). Group I comprised all of four $C$. novyi type A strains. All of four $C$. novyi type B, all of four C. haemolyticum and one C. botulinum type C strain (Stockholm) were included in group II. Group III comprised $C$. botulinum type C 85-8, 95-2, 98-1 and 85-14. The group II and III organisms showed 26 to $49 \%$ homology with reference DNA from C. novyi type A 140 (group I), whereas the group III organisms showed 68 to $70 \%$ homology with reference DNA from C. novyi type B 990 (group II) and reciprocally the group II organisms showed 44 to $62 \%$ homology with 
Table 1. Polynucleotide sequence relationships among $C$. novyi types $A$ and $B, C$. haemolyticum and $C$. botulinum type $C$

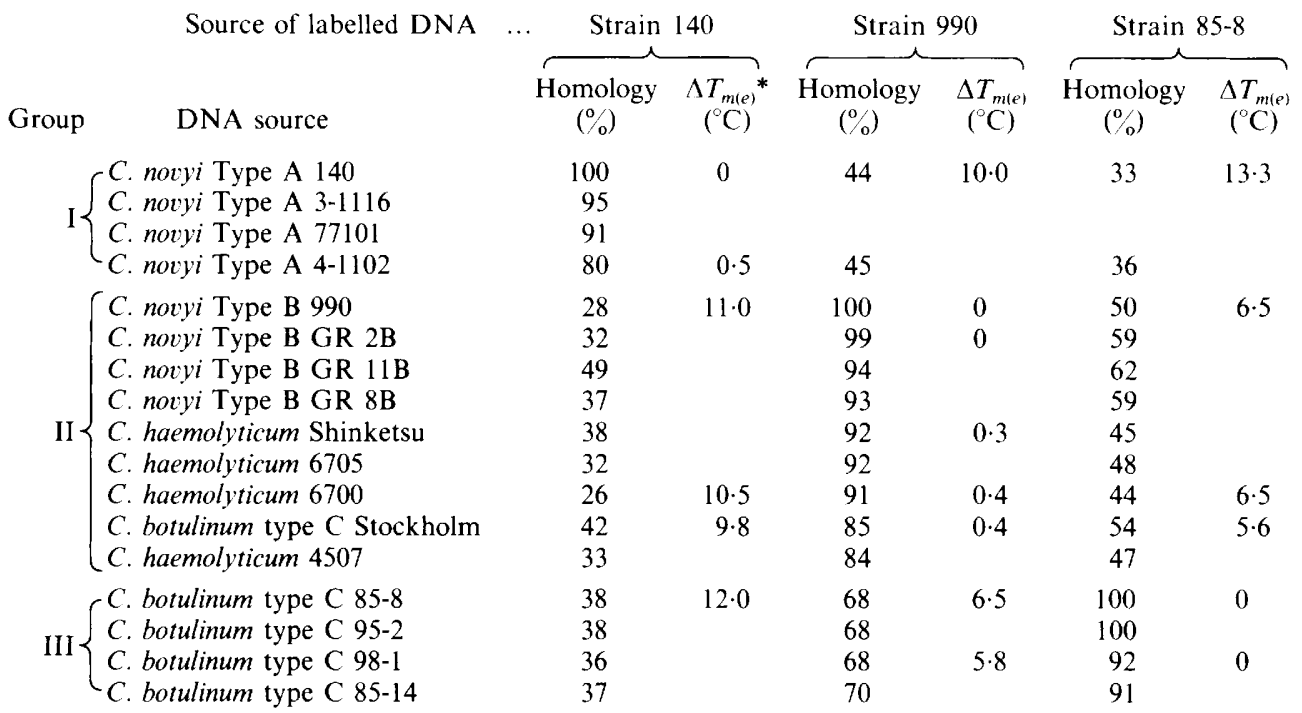

${ }^{*} \Delta T_{m(e)}$ is the difference between the temperatures at which there is $50 \%$ dissociation of homologous and heterologous DNA duplexes.

Table 2. Polynucleotide sequence relationships among $C$. novyi type $B, C$. haemolyticum and $C$. botulinum type $C$

\begin{tabular}{|c|c|c|c|c|c|}
\hline \multirow[b]{2}{*}{ Group } & \multirow[t]{2}{*}{ Source of labelled DNA } & \multicolumn{2}{|c|}{ Strain 6700} & \multicolumn{2}{|c|}{ Strain Stockholm } \\
\hline & & $\begin{array}{c}\text { Homology } \\
(\%)\end{array}$ & $\begin{array}{c}\Delta T_{m(e)}{ }^{*} \\
\left({ }^{\circ} \mathrm{C}\right)\end{array}$ & $\begin{array}{c}\text { Homology } \\
(\%)\end{array}$ & $\begin{array}{c}\Delta T_{\text {m(e) }} \\
\left({ }^{\circ} \mathrm{C}\right)\end{array}$ \\
\hline & C. novyi Тype В 990 & 95 & 0 & 96 & $0 \cdot 2$ \\
\hline & C. novyi Type B GR 2B & 95 & & 86 & 0.2 \\
\hline & C. novyi Type B GR 11B & 91 & & 91 & \\
\hline & C. noryi Type B GR 8B & 89 & & 92 & \\
\hline \multirow[t]{5}{*}{ II } & C. haemolyticum Shinketsu & 89 & $0 \cdot 2$ & 85 & $0 \cdot 5$ \\
\hline & C. haemolyticum 6705 & 93 & & & \\
\hline & C. haemolyticum 6700 & 100 & 0 & 89 & 0.5 \\
\hline & C. botulinum type C Stockholm & 84 & $0 \cdot 3$ & 100 & 0 \\
\hline & C. haemolyticum 4507 & 100 & & 86 & \\
\hline & C. botulinum type C $85-8$ & 59 & & 74 & $5 \cdot 8$ \\
\hline & C. botulinum type C $95-2$ & 67 & & 69 & \\
\hline & C. botulinum type C $98-1$ & 61 & & 69 & $6 \cdot 0$ \\
\hline & C. botulinum type C $85-14$ & 64 & & 66 & \\
\hline
\end{tabular}

* See Table 1.

reference DNA from C. botulinum type C 85-8 (group III). These data suggest that the strains in group II were more closely related to the strains in group III than those in group I.

Further tests were performed to determine the thermostability of the duplexes formed between DNA from C. novyi type A 140 (group I), C. novyi type B 990 (group II) or C. botulinum type C 85-8 (group III) and DNAs from a few strains arbitrarily selected from groups I, II and III. The $T_{m(e)}$ values for the DNA duplexes between group II strains and $C$. novyi type B 990 (group II) were similar to that of homologous DNA duplexes of $C$. novyi type B $990\left(\Delta T_{m(e)} 0\right.$ to $0 \cdot 4^{\circ} \mathrm{C}$ ). The $T_{m(e)}$ values for the DNA duplexes between group II strains and $C$. novyi type A 140 (group I) were 9.8 to $11.0^{\circ} \mathrm{C}$ lower than that of homologous DNA duplexes of $C$. novyi type A 140. The $T_{m(e)}$ values for the DNA duplexes between group II strains and $C$. botulinum type 
Table 3. Biochemical properties for differentiation of strains in groups I, II and III

\begin{tabular}{|c|c|c|c|}
\hline Property & Group I & Group II & Group III \\
\hline \multicolumn{4}{|l|}{ Fermentation of: } \\
\hline Glucose & $4 / 4$ & $9 / 9$ & $4 / 4$ \\
\hline Ribose & $4 / 4$ & $9 / 9$ & $4 / 4$ \\
\hline Fructose & $2 / 4$ & $9 / 9$ & $4 / 4$ \\
\hline Inositol & $2 / 4$ & $9 / 9$ & $4 / 4$ \\
\hline Maltose & $4 / 4$ & $8 / 9$ & $4 / 4$ \\
\hline Mannose & $0 / 4$ & $9 / 9$ & $4 / 4$ \\
\hline Melibiose & $0 / 4$ & $0 / 9$ & $4 / 4$ \\
\hline Galactose & $0 / 4$ & $0 / 9$ & $4 / 4$ \\
\hline \multicolumn{4}{|l|}{ Liquefaction of gelatin: } \\
\hline $2 \%(\mathrm{w} / \mathrm{v})$ & $4 / 4$ & $9 / 9$ & $4 / 4$ \\
\hline $10 \%(\mathrm{w} / \mathrm{v})$ & $3 / 4$ & $0 / 9$ & $3 / 4$ \\
\hline Production of indole & $3 / 4$ & $9 / 9$ & $0 / 4$ \\
\hline Digestion of milk & $3 / 4$ & $9 / 9$ & $0 / 4$ \\
\hline Digestion of casein & $3 / 4$ & $0 / 9$ & $0 / 4$ \\
\hline
\end{tabular}

Table 4. Lecithinase neutralization of Nagler's $m$-VFBA

Strains were differentiated into groups based on DNA-DNA homology (see Table 1).

\begin{tabular}{|c|c|c|}
\hline \multirow[b]{2}{*}{ Group } & \multicolumn{2}{|c|}{$\begin{array}{c}\text { Lecithinase neutralization } \\
\text { by antitoxin serum } \\
\text { against } C \text {. novyi types }\end{array}$} \\
\hline & A & B \\
\hline I & + & - \\
\hline II & - & + \\
\hline III & - & + \\
\hline
\end{tabular}

C 85-8 (group III) were 5.6 to $6.5^{\circ} \mathrm{C}$ lower than that of homologous DNA duplexes of $C$. botulinum type $\mathrm{C} 85-8$. These data again confirmed the closer genetic relationship between groups II and III.

A further study with labelled DNAs from C. botulinum type C Stockholm and C. haemolyticum 6700 confirmed that there were two genetically different groups in $C$. botulinum type $\mathrm{C}$ and that $C$. haemolyticum, $C$. novyi type $\mathbf{B}$ and $C$. botulinum type $C$ Stockholm were genetically homologous (Table 2).

\section{Biochemical properties}

Biochemical properties were examined to find the differential criteria corresponding to the genetic differences mentioned above (Table 3 ). In the test for sugar fermentation, the $\mathrm{pH}$ of the $3 \mathrm{~d}$ cultures without sugar added was usually $6 \cdot 3$ or 6.4 . Although some of the strains, in the presence of a certain sugar, exhibited only a slight $\mathrm{pH}$ fall, these strains were evaluated as being fermentation-positive because they showed distinctly abundant growth in the presence of the sugar, relative to that in the absence of the sugar. Final $\mathrm{pH}$ in these fermentation-positive cases usually ranged between $5 \cdot 7$ and $6 \cdot 1$. Useful criteria for differentiation were as follows: none of group I strains fermented mannose, while all strains of groups II and III fermented this sugar; none of group II strains fermented melibiose and galactose, while all strains of group III fermented the two sugars; none of group III strains produced indole nor digested milk, while all strains in group II were positive for these two characters.

No distinct difference, except for lipase production, was found among strains of group II, although they were designated by different names, i.e. $C$. novyi type $\mathrm{B}, C$. haemolyticum and $C$. botulinum type C. In the test for lipase production on Nagler's m-VFBA, C. botulinum type C Stockholm (group II) was positive but all the $C$. novyi type B and $C$. haemolyticum strains were negative. All strains of $C$. botulinum type $C$ in group III were positive in the lipase test. 


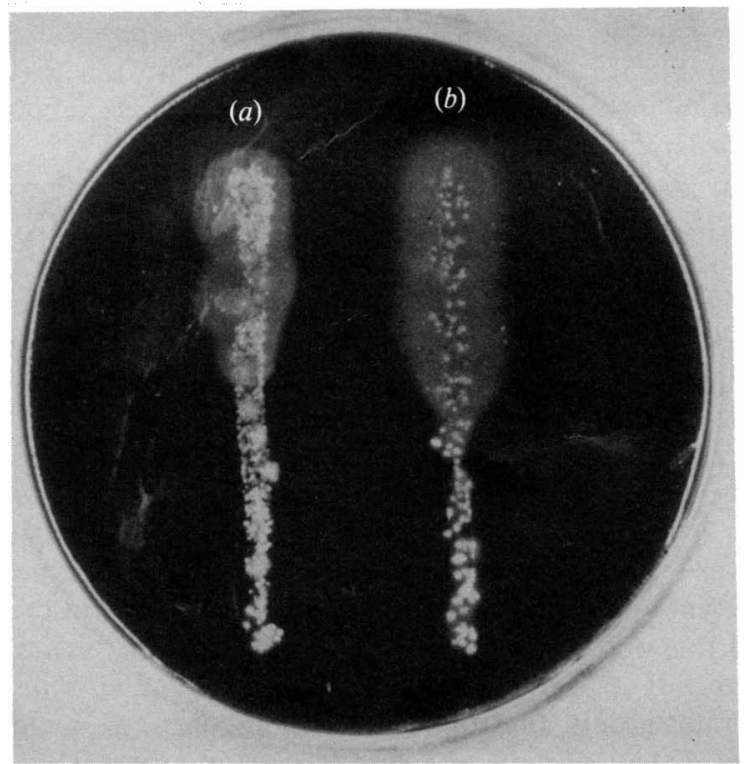

Fig. 1. Lecithinase reaction of $C$. novyi type B $990(a)$ and $C$. botulinum type C 85-8 (b) on half-antitoxin Nagler's m-VFBA spread with the antitoxin serum of $C$. novyi type B.

\section{Lecithinase neutralization test}

A neutralization test for lecithinase reaction of $C$. botulinum type $C, C$. novyi types $\mathrm{A}$ and $\mathrm{B}$, and $C$. haemolyticum was performed on half-antitoxin Nagler's m-VFBA spread with the antitoxin serum of $C$. novyi type A or B. The antitoxin serum of $C$. novyi type A specifically suppressed the lecithinase reaction of $C$. novyi type A, whereas that of $C$. novyi type B suppressed the lecithinase reaction of $C$. botulinum type $C$ in groups II and III as well as that of $C$. novyi type B and C. haemolyticum (Table 4, Fig. 1).

\section{DISCUSSION}

The present study on DNA-DNA homology showed that $C$. novyi types $\mathrm{A}$ and $\mathrm{B}, C$. haemolyticum, and $C$. botulinum type $\mathrm{C}$ strains were genetically divided into groups $\mathrm{I}(C$. novyi type A), II ( $C$. novyi type B, C. haemolyticum and one $C$. botulinum type $\mathrm{C}$ strain) and III (C. botulinum type C). Smith \& Hobbs (1974) found that $C$. haemolyticum and $C$. novyi type B are separate species, although the major lethal toxin of $C$. haemolyticum is identical with the beta toxin of C. novyi type B (Oakley \& Warrack, 1959; Oakley et al., 1974) and the cultural properties of the two species resembled each other very closely (Holdeman \& Moore, 1975; Nakamura et $a l ., 1975 b$; Roberts et al., 1970; Rutter, 1970). The present study shows that $C$. haemolyticum and C. novyi type B comprise one genetically homologous group (group III). In PAGE analysis of soluble cellular proteins of the two species, Cato et al. (1982) also demonstrated that the patterns of $C$. novyi type B and $C$. haemolyticum were indistinguishable. As for the alpha toxin, the main difference between the two species, it has already been demonstrated that the alpha toxigenesis in $C$. novyi type B and $C$. haemolyticum was intimately related with phage infection; $C$. novyi type $B$, when cured of a certain phage, ceased to produce its alpha toxin and again produced it when the phage-sensitive cultures were reinfected with the phage (Eklund et al., 1976), while $C$. haemolyticum, when infected with phage of $C$. novyi type $\mathrm{A}$, produced the alpha toxin (Schallehn \& Eklund, 1980). It appears, therefore, that $C$. haemolyticum should be considered as C. novyi type D as Oakley \& Warrack (1959) suggested.

The present test for DNA-DNA homology revealed that C. botulinum type C Stockholm was genetically different from the remaining type $\mathrm{C}$ strains (group III) that were isolated from 
marine sediments (Serikawa et al., 1977). For practical purposes, however, the name $C$. botulinum is still preferable for the strain Stockholm because the toxicity of this strain is neutralizable by the common antitoxin serum for $C$. botulinum type $\mathrm{C}$ but not by that for $C$. novyi type $\mathrm{B}$ or $C$. haemolyticum.

Some comments may be needed concerning the differences in reciprocal crosses of DNADNA homology values $(\%)$ among reference DNAs of groups I, II and III, although the data are scant. The difference between groups I and III was small (strain $140 \times$ strain $85-8=38 \%$; strain $85-8 \times$ strain $140=33 \%$ : difference $5 \%$, while the differences were 15 to $24 \%$ between groups II and III, and $16 \%$ between groups I and II. One explanation for these larger differences could be that the genome size of group II may be smaller than those of the two other groups.

Although carbohydrate fermentation properties of $C$. novyi types $\mathrm{A}$ and $\mathrm{B}$, and $C$. haemolyticum vary somewhat from one strain to another and also from one laboratory to another (Holdeman \& Moore, 1975; Roberts et al., 1970; Rutter, 1970), Holdeman \& Moore (1975) stated that mannose was fermented by most of $C$. novyi type B and $C$. haemolyticum strains but not by any of $C$. novyi type A strains, when the test was performed in the PRAS medium. Our results also confirmed this observation; none of group I strains (C. novyi type A) fermented mannose but all of group II strains did ferment this sugar. The $C$. botulinum type $C$ strain in group III differed from group II strains in fermentation of melibiose and galactose. Fermentation patterns of the $C$. botulinum type $C$ strains in group III were similar to those of marine strains of $C$. botulinum type C described by Segner et al. (1971), who stated that the marine and terrestrial strains of $C$. botulinum type $C$ were different from each other in carbohydrate fermentation.

\section{REFERENCES}

Cato, E. P., Holdeman, L. V. \& Moore, W. E. C. (1982). Electrophoretic study of Clostridium species. Journal of Clinical Microbiology 15, 688-702.

EkLUNd, M. W. \& Poysky, F. T. (1972). Activation of a toxic component of Clostridium botulinum types $\mathrm{C}$ and D by trypsin. Applied Microbiology 24, 108-113.

Eklund, M. W., Poysky, F. T., Meyers, J. A. \& PelroY, G. A. (1974). Interspecies conversion of Clostridium botulinum type $\mathrm{C}$ to Clostridium novyi type A by bacteriophage. Science 186, 456-458.

Eklund, M. W., Poysky, F. T., Peterson, M. E. \& MEYeRS, J. A. (1976). Relationship of bacteriophages to alpha toxin production in Clostridium novyi types A and B. Infection and Immunity 14, 793-803.

Holdeman, L. V. \& Brooks, J. B. (1970). Variation among strains of Clostridium botulinum and related clostridia. In Proceedings of the First U.S.-Japan Conference on Toxic Microorganisms, pp. 278-286. Edited by M. Herzberg. Washington, D.C. : Government Printing Office.

Holdeman, L. V. \& MoOre, W. E. C. (editors) (1975). Anaerobe Laboratory Manual, 3rd edn. Blacksburg, Virginia, U.S.A.: V.P.I. Anaerobe Laboratory.

INoue, E. \& IIDA, H. (1970). Conversion of toxigenicity in Clostridium botulinum type C. Japanese Journal of Microbiology 14, 87-89.

MARMUR, J. (1961). A procedure for the isolation of deoxyribonucleic acid from microorganisms. Journal of Molecular Biology 3, 208-218.

NAGLER, F. P. O. (1944). Bacteriological diagnosis of gas gangrene due to Clostridium oedematiens. Nature, London 153, 496.

Nakamura, S., Shimamura, T., Hayase, M. \& NisHIDA, S. (1973). Numerical taxonomy of saccharolytic clostridia, particularly Clostridium per- fringens-like strains; description of Clostridium absonum sp. $\mathrm{n}$. and Clostridium paraperfringens. International Journal of Systematic Bacteriology 23, 419. 429

Nakamura, S., Shimamura, T., Hayashi, H. \& NISHIDA, S. (1975a). Reinvestigation of the taxonomy of Clostridium bifermentans and Clostridium sordellii. Journal of Medical Microbiology 8, 299-309.

NaKamura, S., TAKEMatSU, K. \& Nishida, S. (1975b). Susceptibility to mitomycin $\mathrm{C}$ and lecithinase activities of Clostridium oedematiens (C. novyi) types B and D. Journal of Medical Microbiology 8, 289-297.

Nakamura, S., Serikawa, T., Yamakawa, K., Nishida, S., Kozaki, S. \& SaKaguChI, G. (1978). Sporulation and $C_{2}$ toxin production by Clostridium botulinum type $\mathrm{C}$ strains producing no $\mathrm{C}_{1}$ toxin. Microbiology and Immunology 22, 591-596.

Nishida, S. \& NaKagawara, G. (1964). Isolation of toxigenic strains of Clostridium novyi from soil. Journal of Bacteriology 88, 1636-1640.

Nishida, S. \& NaKagawara, G. (1965). Relationship between toxigenicity and sporulating potency of Clostridium novyi. Journal of Bacteriology 89, $167-$ 169.

OAKLEY, C. L. \& WarRack, G. H. (1959). The soluble antigens of Clostridium oedematiens type D $(\mathrm{Cl}$. haemolyticum). Journal of Pathology and Bacteriology 78, 543-551.

OAKley, C. L., Warrack, G. H. \& Clarke, P. H. (1947). The toxins of Clostridium oedematiens $(\mathrm{Cl}$. novyi). Journal of General Microbiology 1, 91-107.

Roberts, R. S., Guven, S. \& Worrall, E. E. (1970). Studies on Clostridium oedematiens. Journal of Comparative Pathology 80, 9-18.

RUTTER, J. M. (1970). A study of the carbohydrate 
fermentation reaction of Clostridium oedematiens $(\mathrm{Cl}$. notyi). Journal of Medical Microbiology 3, 283-289.

Rutter, J. M. \& Collee, J. G. (1969). Studies on the soluble antigens of Clostridium oedematiens $(\mathrm{Cl}$. novyi). Journal of Medical Microbiology 2, 395-417.

SChallehn, G. \& Eklund, M. W. (1980). Conversion of Clostridium novyi type D (C. haemolyticum) to alpha toxin production by phages of $C$. novyi type A. FEMS Microbiology Letters 7, 83-86.

Segner, W. P., SChmidt, C. F. \& Boltz, J. K. (1971). Enrichment, isolation, and cultural characteristics of marine strains of Clostridium botulinum type C. Applied Microbiology 22, 1017-1024.

Serikawa, T., Nakamura, S. \& Nishida, S. (1977). Distribution of Clostridium botulinum type $\mathrm{C}$ in Ishikawa Prefecture, and applicability of agglutina- tion to identification of nontoxigenic isolates of Clostridium botulinum type C. Microbiology and Immunology 21, 127-136.

Smith, L. DS. (1975). The Pathogenic Anaerobic Bacteria, 2nd edn, pp. 271-280. Springfield: Charles C. Thomas, Publisher.

SMITH, L. DS. \& HoBBs, G. (1974). Clostridium. In Bergey's Manual of Determinative Bacteriology, 8th edn, pp. 551-572. Edited by R. B. Buchanan \& N. E. Gibbons. Baltimore: Williams \& Wilkins.

Taguchi, R. \& Ikezawa, H. (1975). Phospholipase C from Clostridium novyi type A I. Biochimica et biophysica acta 409, 75-85.

WiLlis, A. T. (1964). Anaerobic Bacteriology in Clinical Medicine, 2nd edn, pp. 80-83. London: Butterworths. 